\title{
Determination of Physical and Mechanical Properties of Wood Specie Dinizia excelsa Ducke
}

\author{
Natália Garcia Couto ${ }^{1}$, Vinicius Borges de Moura Aquino ${ }^{1}$, João Paulo Boff Almeida ${ }^{1}$, \\ Diego Henrique de Almeida ${ }^{2}$, André Luis Christoforo ${ }^{1, *}$, Francisco Antonio Rocco Lahr ${ }^{3}$ \\ ${ }^{1}$ Department of Civil Engineering (DECiv), Federal University of São Carlos (UFSCar), São Carlos, Brazil \\ ${ }^{2}$ Department of Civil Engineering, Federal University of Rondônia Foundation (UNIR), Rondônia, Brazil \\ ${ }^{3}$ Department of Structural Engineering (SET), São Carlos Engineering School, São Paulo University (EESC/USP), São Carlos, Brazil
}

\begin{abstract}
Wood is a material, when compared with other materials applied in civil construction, displays several advantages such an elevated mechanical strength when related with its apparent density. The wood manufacturing industry has great representativeness in the Brazilian economy however, the irrational consumption of determined species brought damages to the forest, causing extinction of some species and consequently, rising wood prices in market. The characterization of unknown wood species presents an alternative for a more rational exploration and expand wood use in structural purpose, enabling the use of this species determining its properties. The study aimed to characterize 3 physical properties and 12 mechanical properties of Angelim vermelho (Dinizia excelsa Ducke.) based on Brazilian Standard ABNT NBR 7190. Twelve models were used for each test, totalizing 180 experimental results. The analysis of variance (ANOVA) handling the regression models will be used to predict the strength and stiffness as function of apparent density. The results presented on tests demonstrated compatible performance with common wood species used in civil construction, considered high strength wood and with adequate use in this activity. According the regression models, only three properties were considered significant with apparent density estimation.
\end{abstract}

Keywords Characterization, Dinizia excelsa Ducke, Regression model, Analysis of variance (ANOVA)

\section{Introduction}

Wood is a functional material due its anatomical characteristics, physical and mechanical properties. Also is a renewable material compared to others used in civil construction, like concrete, steel and aluminum, presents advantages as elevated mechanical strength in relation to mass, low energetic consumption in its processing and good thermal isolation [1].

Brazil is highlighted in world scene when it refers to the wood manufacturing industry due to the diversity of native forests and the planted forest productivity. The high native forest wood consumption for a long time led to a nearly extinction of many economic value wood species [2]. Wood harvest, mainly Amazonian native wood species, has been done in a uncontrolled form bringing enormous losses to the forests and ignoring high potential unknown wood species [3].

* Corresponding author:

alchristoforo@gmail.com (André Luis Christoforo)

Published online at http://journal.sapub.org/ijme

Copyright $\odot 2018$ The Author(s). Published by Scientific \& Academic Publishing This work is licensed under the Creative Commons Attribution International License (CC BY). http://creativecommons.org/licenses/by/4.0/
Among the sectors that use wood as raw material, civil construction sector is the one of the most exigent in terms of physical and mechanical properties. Then, it causes a certain limitation in the number of wood species with characteristics that could be used in this sector $[4,5]$.

The knowledge of physical and mechanical properties results in a better utilization of wood species that is constantly rejected due to lack of information. It is important a transformation in this scenario for the wood structures become more competitive when compared to other types of materials [6].

According Dias and Lahr [7], the methods of unknown wood species tests established on the Brazilian Standard ABNT NBR 7190 [8] demands the use large and expensive equipment available in research centers. Therefore, many times wood is used without knowledge of its characteristics, which leads to its waste.

Otherwise, a physical property of easy determination experimentally is the apparent density, defined by the ratio between the mass and volume of the sample at $12 \%$ moisture. Considering that density is a basic physical property, its value endorses the estimation of some wood properties $[9,10]$. The estimation of strength and stiffness properties by density via mathematical methods (regression methods) enables the engineer a better pre-design of the structure. 
The wood Dinizia excelsa Ducke., displayed in Figure 1, present in Brazilian states of Acre, Rondônia, Amazonas, Pará, Roraima, Amapá e Maranhão becomes a great option, especially to Amazonian part of Brazil, the west and southeast part of Brazilian country, where the production of this wood specie is more noticeable [11].

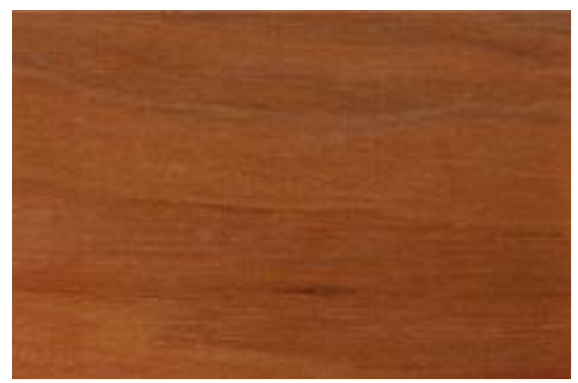

Figure 1. Image of the Dinizia excelsa Ducke, Source: http://www.ipt.br/informacoes_madeiras/23.html

Observing the exposed, the study aims to characterize the Dinizia excelsa wood specie and evaluate the possibility of estimating physical and mechanical properties in function of apparent density.

\section{Material and Methods}

The wood samples of the Dinizia excelsa Ducke has been properly stored, close to $12 \%$ moisture content, the moisture balance established by the Brazilian standard [8].

All tests were carried out on the Laboratory of Wood and Wood Structures (Laboratório de Madeira e de Estruturas de Madeira - LaMEM), at the São Carlos Engineering School (EESC), University of São Paulo (USP).

The physical and mechanical properties (Table 1) were obtained according to the assumptions and calculation methods given by the Brazilian standard ABNT NBR 7190 [7] (Wooden Structures Project), provided on its Annex B. It should be noted that 12 values for each one of its physical (3) and mechanical properties (12) were investigated, resulting in a total of 180 experimental values obtained.

In addition to obtaining the physical and mechanical properties listed in Table 1, the wood Dinizia excelsa Ducke has been properly classified in the timber strength classes [8], defined by determining its characteristic value of compressive strength parallel to the grain $\left(\mathrm{f}_{\mathrm{c} 0 \mathrm{k}, \mathrm{k}}\right)$.

To estimate the strength and the stiffness properties $(Y)$, as a function of the apparent density $\left(\rho_{12}\right)$ of the Dinizia excelsa Ducke wood specie, regression models were used (Equations 1 to 4) based on analysis of variance (ANOVA), tested in a way to establish the best fit for estimated property.

$$
\begin{aligned}
& Y=a+b \cdot \rho_{12} \quad[\text { Lin - linear }] \\
& Y=a \cdot e^{b \cdot \rho_{12}} \quad[\text { Exp - exponential }] \\
& Y=a+b \cdot \operatorname{Ln}\left(\rho_{12}\right) \quad[\text { Log - logarithmic }] \\
& Y=a \cdot \rho_{12}{ }^{b} \quad[\text { Geo - geometric }]
\end{aligned}
$$

By ANOVA regression models, considering the 5\% level of significance $(\alpha)$, the formulated null hypothesis consisted by the non-representativeness of the tested models $\left(H_{0}: \beta=\right.$ 0 ), and the representativeness as an alternative hypothesis $\left(H_{1}: \beta \neq 0\right)$. P-value greater than the significance level implies in the accepting $\mathrm{H}_{0}$ (the model tested is not representative $-\rho_{12}$ variations are unable to explain the variation in strength and stiffness property), refuting it otherwise (the model tested is representative).

Besides the use of ANOVA, which allows to accept or not the representativeness of the tested models, the coefficient of determination values $\left(R^{2}\right)$ were obtained as a way to evaluate the variation capability in the apparent density to explain the estimated dependent variable, making it possible to determine, among the considered significant models (4 models for each of the 14 strength properties and estimated stiffness - resulting in 48 adjustments), the ones with the best fit.

Table 1. Mechanical and physical properties measured for the Dinizia excelsa Ducke wood specie

\begin{tabular}{lc}
\hline \multicolumn{1}{c}{ Properties } & Notation \\
\hline Apparent density & $\rho_{12}$ \\
Total radial Shrinkage & $\mathrm{RRT}$ \\
Total tangencial Shrinkage & $\mathrm{RTT}$ \\
Compressive strength parallel to the grain & $\mathrm{f}_{\mathrm{c} 0}$ \\
Tensile strength parallel to the grain & $\mathrm{f}_{\mathrm{t} 0}$ \\
Tensile strength normal to the grain & $\mathrm{f}_{\mathrm{t} 90}$ \\
Shear strength parallel to the grain & $\mathrm{f}_{\mathrm{v} 0}$ \\
Splitting strength & $\mathrm{f}_{\mathrm{s} 0}$ \\
Conventional strength on static bending test & $\mathrm{f}_{\mathrm{m}}$ \\
Modulus of elasticity in parallel directions to the grain & $\mathrm{E}_{\mathrm{c} 0}$ \\
Modulus of elasticity in tension parallel to the grain & $\mathrm{E}_{\mathrm{t} 0}$ \\
Conventional modulus of elasticity on static bending & $\mathrm{E}_{\mathrm{m}}$ \\
test & \\
Hardness parallel to the grain & $\mathrm{f}_{\mathrm{H} 0}$ \\
Hardness normal to the grain & $\mathrm{f}_{\mathrm{H} 90}$ \\
Toughness & $\mathrm{W}$ \\
\hline
\end{tabular}

\section{Results and Discussion}

Tables 2 and 3 shows the mean values $(\bar{x})$, coefficient of variation $(C v)$, the lowest (Min) and the highest (Max) of the physical and mechanical properties of the Dinizia excelsa Ducke wood, respectively.

Table 2. Physical properties results for the Dinizia excelsa Ducke wood

\begin{tabular}{cccc}
\hline Stat. & $\boldsymbol{\rho}_{\mathbf{1 2}}\left(\mathbf{k g} / \mathbf{m}^{\mathbf{3}}\right)$ & RRT $(\%)$ & RTT $(\%)$ \\
\hline $\bar{x}$ & 1130 & 5.10 & 8.42 \\
Cv & 0.10 & 0.12 & 0.08 \\
Min & 990 & 4.40 & 7.44 \\
Max & 1250 & 6.54 & 9.68 \\
\hline
\end{tabular}


Table 3. Mechanical properties results for the Dinizia excelsa Ducke wood

\begin{tabular}{ccccc}
\hline Stat. & $\mathbf{f}_{\mathbf{c} 0}(\mathbf{M P a})$ & $\mathbf{f}_{\mathbf{t} \mathbf{0}}(\mathbf{M P a})$ & $\mathbf{f}_{\mathbf{t} \mathbf{0}}(\mathbf{M P a})$ & $\mathbf{f}_{\mathbf{v} \mathbf{0}}(\mathbf{M P a})$ \\
\hline $\bar{x}$ & 78 & 105 & 4.8 & 19 \\
$C v$ & 0.08 & 0.33 & 0.28 & 0.23 \\
Min & 66 & 59 & 2.8 & 12 \\
Max & 90 & 198 & 8.1 & 26 \\
\hline Stat. & $\mathbf{f}_{\mathbf{s} 0}(\mathbf{M P a})$ & $\mathbf{f}_{\mathbf{m}}(\mathbf{M P a})$ & $\mathbf{E}_{\mathbf{c} \mathbf{0}}(\mathbf{M P a})$ & $\mathbf{E}_{\mathbf{t} \mathbf{0}}(\mathbf{M P a})$ \\
\hline $\bar{x}$ & 0.9 & 110 & 16695 & 17024 \\
$C v$ & 0.12 & 0.14 & 0.18 & 0.17 \\
Min & 0.7 & 87 & 9494 & 12842 \\
Max & 1.0 & 129 & 20935 & 22730 \\
\hline Stat. & $\mathbf{E}_{\mathbf{m}}(\mathbf{M P a})$ & $\mathbf{f}_{\mathbf{H} \mathbf{0}}(\mathbf{M P a})$ & $\mathbf{f}_{\mathbf{H} \mathbf{0} \mathbf{0}}(\mathbf{M P a})$ & $\mathbf{W}(\mathbf{N} \cdot \mathbf{m})$ \\
\hline $\bar{x}$ & 15632 & 146 & 137 & 19,8 \\
$C v$ & 0.09 & 0.14 & 0.15 & 0.35 \\
Min & 12863 & 101 & 98 & 10.10 \\
Max & 18093 & 165 & 160 & 30.10 \\
\hline
\end{tabular}

Considering the experimental results, the characteristic compressive strength parallel to the grain $\left(f_{c 0, k}\right)$ was equal to $72 \mathrm{MPa}$ [8], which fits the Dinizia excelsa Ducke wood in the C60 strength class.

The average compressive strength parallel to the grain $\left(\mathrm{f}_{\mathrm{c}, 0 \mathrm{k}}\right)$ was $78 \mathrm{MPa}$, close to the result obtained by Grobério and Lahr (77.5 MPa) [12] with the same wood specie and higher when compared with Mimosa tenuiflora (58.25 MPa) [13], Mimosa schomburgkii (64.7 MPa) [4], Toona ciliata (27 MPa) [14], Eucalyptus camaldulensis (25.3 MPa) [15] e Eucalyptus benthamii (37.34 MPa) [16].

The average apparent density $\left(\rho_{12}\right)$ was $1.13 \mathrm{~g} / \mathrm{cm}^{3}$, considered by Grobério and Lahr a very heavy wood [12]. This value $\left(1.13 \mathrm{~g} / \mathrm{cm}^{3}\right)$ was close to the Mimosa tenuiflora $\left(1.06 \mathrm{~g} / \mathrm{cm}^{3}\right)$ [13] and higher than Minquartia guianensis, Manilkara huber, Lecythis poiteaui e Mezilaurus itauba, whose density vary between 0.867 and $0.907 \mathrm{~g} / \mathrm{cm}^{3}$ [17]. Comparing with Eucalyptus grandis and Eucalyptus cloeziana [18], whose density range between 0.59 and 0.67 $\mathrm{g} / \mathrm{cm}^{3}$, Dinizia excelsa Ducke presents a heavy wood.

Brazilian Standard ABNT NBR 7190 [8] defines the maximum value for the coefficient of variation $(\mathrm{Cv})$ for the characterization to be considered as adequate, being $18 \%$ for strength in normal stresses and $28 \%$ for tangential efforts. All properties met the values of the coefficients of variation required by the standard, but the tensile strength parallel to the grain $\left(f_{t}\right)$, shear strength parallel to the grain $\left(f_{v 0}\right)$ and toughness $(\mathrm{W})$ which exceed the limit, showing a $C v$ equal to $0.33,0.23$ and 0.35 , respectively.

According Grobério and Lahr [11], there is the possibility the use of Dinizia excelsa Ducke in civil construction, including heavy duty use, structural purpose and furniture use.
Table 4. Regression models for the strength values estimation of the Dinizia excelsa Ducke by the apparent density

\begin{tabular}{cccccc}
\hline & Model & P-value & a & B & $\mathbf{R}^{\mathbf{2}(\%)}$ \\
\hline $\mathbf{f}_{\mathbf{c 0}}$ & Lin. & 0.2772 & 57.0412 & 18.1213 & 11.67 \\
$\mathbf{f}_{\mathbf{t 0}}$ & Lin & 0.3301 & -4.3164 & 96.5804 & 9.48 \\
$\mathbf{f}_{\mathbf{t 9 0}}$ & Lin & 0.7993 & 6.004 & -1.0279 & 0.68 \\
$\mathbf{f}_{\mathbf{v 0}}$ & Geo & 0.0231 & 15.1767 & 1.5241 & 41.78 \\
$\mathbf{f}_{\mathbf{s 0}}$ & Log & 0.6591 & 0.8901 & 0.1541 & 2.02 \\
$\mathbf{f}_{\mathbf{m}}$ & Exp & 0.9488 & 105.9636 & 0.0266 & 0.04 \\
$\mathbf{f}_{\mathbf{H 0}}$ & Log & 0.0085 & 128.8897 & 142.7716 & 51.57 \\
$\mathbf{f}_{\mathbf{H 9 0}}$ & Geo & 0.0177 & 120.0967 & 1.0229 & 44.53 \\
$\mathbf{W}$ & Geo & 0.1956 & 1.5658 & 1.4814 & 15.97 \\
\hline
\end{tabular}

Table 5. Regression models for the stiffness values estimation of the Dinizia excelsa Ducke by the apparent density

\begin{tabular}{lccccc}
\hline & Model & P-value & $\mathbf{a}$ & $\mathbf{b}$ & $\mathbf{R}^{\mathbf{2}(\boldsymbol{\%})}$ \\
\hline $\mathbf{E}_{\mathbf{c} \mathbf{0}}$ & $\operatorname{Exp}$ & 0.6750 & 21848.8375 & -0.2535 & 1.83 \\
$\mathbf{E}_{\mathbf{t} \mathbf{0}}$ & $\log$ & 0.8398 & 16798.6334 & 1905.0596 & 0.43 \\
$\mathbf{E}_{\mathbf{m}}$ & $\operatorname{Exp}$ & 0.7447 & 14095.8894 & 0.0881 & 1.11 \\
\hline
\end{tabular}

The models which presents p-value below 0.05 are considered significant. Good quality in the adjustment is represented when the coefficient of determination $\left(\mathrm{R}^{2}\right)$ is over $34 \%$, being significant for $\mathrm{R}^{2}$ values between $60 \%$ and $70 \%$ and higher [19]. The estimated properties with good quality in the adjustment were: $\mathrm{f}_{\mathrm{v} 0}, \mathrm{f}_{\mathrm{H} 90}, \mathrm{f}_{\mathrm{HO}}$. However, any property was considered significant $\left(\mathrm{R}^{2}\right.$ close or higher than $60 \%$ ), with the hardness parallel to the fibers $\left(\mathrm{f}_{\mathrm{H} 0}\right)$ presenting the major value $(51.57 \%)$. Figure 2 illustrate the adjustment for $\mathrm{f}_{\mathrm{H} 0}$.

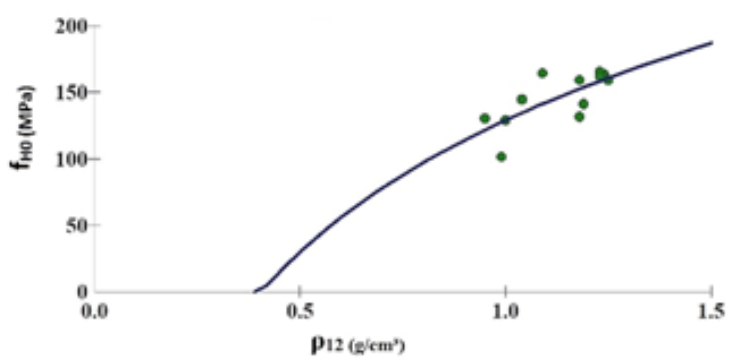

Figure 2. Best fit obtained to estimate the strength values of wood by apparent density - logarithmic

The value of determination coefficient near $80 \%$ for the toughness adjustment obtained by Almeida et. al. [10] was significantly different from the determination coefficient (15.97\%) obtained for Dinizia excelsa Ducke wood specie. Such divergence can be justified due to use of more wood specimens and variable density, which favors the best quality in the adjustment.

In the study developed by Dias and Lahr [7], the relation of apparent density with tensile strength normal to the grain and splitting strength obtained coefficient of determination $\left(\mathrm{R}^{2}\right)$ with low values, just as for Dinizia excelsa Ducke. It evidences a low correlation between apparent density and this properties. 


\section{Conclusions}

The results of this study permit us to conclude:

- According the limit values for the variation coefficient established by the Brazilian Standard, the results obtained for the characterization are valid;

- Following the Brazilian Standard parameters, this wood is classified as C60 wood due to its characteristic compression strength parallel to the grain of $72 \mathrm{MPa}$, indicating the potential use of this wood specie in civil construction heavy duty use, structural demand and furniture use;

- The regression models of apparent density as an estimator of strength and stiffness properties were significant for only three $\left(\mathrm{f}_{\mathrm{v} 0}, \mathrm{f}_{\mathrm{H} 0}\right.$ and $\left.\mathrm{f}_{\mathrm{H} 90}\right)$ of 14 analyzed properties, displaying a good quality in the adjustment in these three properties but not being significant.

\section{REFERENCES}

[1] Vidal, J. M.; Evangelhista, W. V.; Silva, J. C.; Jankowsky, I. P. Preservação de madeiras no Brasil: Histórico, cenário atual e tendências, Ciência Florestal, Santa Maria - RS, v. 25, n. 1, p. 257-271, jan./mar. 2015.

[2] Freitas, T. P.; Feuchard, L. D.; Oliveira, J. T. S.; Paes J. B.; Arantes, M. D. C. Caracterizações anatômicas e físico-mecânica da madeira Liquidambar sp., Floresta, Curitiba - PR, v. 45, n.4, p. 723 - 734, dez. 2014.

[3] Carvalho, J.O.P.; Santos, J. J.; Saldanha, E.B.; Melo, A.S.G; Nascimento, S. M; Hirai, E. H.; Castro, T. C; Coelho, A. A; Batista, R. W. C. Identificação botânica de espécies arbóreas pouco conhecidas como contribuição ao planejamento do manejo de florestas naturais no estado do Pará. In: Anais da I Conferência do Subprograma de Ciência e Tecnologia; 2008; Belém. Brasília: CNPq; 2009. p. 579.

[4] Costa, L. J.; Lopes, C. B. S.; Reis, M. F. C.; Candido, W. L.; Faria, B. F. H.; Paula, M. O. Caracterização anatômica e descrição físico-quimica e mecânica da madeira de Mimosa schomburgkii. Floresta, Curitiba - PR, v. 47, n. 4, p. 383-390, out./dez., 2017.

[5] Iwakiri, S.; Trianoski, R.; Fonte, A. P. N.; França, M. C.; Lau, P. C.; Molleken, R. Potencial de uso de madeiras de Dinizia excelsa Ducke e Protium puncticulatum J.F.Macbr para produção de paineis EGP. Scientia Forestalis, Piracicaba-SP, v. 44, n. 111, p. 709-717, set. 2016.

[6] Lahr, F. A. R.; Propriedades físicas de resistência e de elasticidade de espécies de madeira para emprego em estruturas, Encontro Brasileiro de Madeiras e em Estruturas de Madeiras, v. 3, São Carlos, SP, Brasil, 1989.
[7] Dias, F. M.; Lahr, F. A. R. Estimativa de propriedades de resistência e rigidez da madeira através da densidade aparente, Scientia Florestalis, Piracicaba - SP, n. 65, p. 102 - 113, jun. 2004.

[8] Associação Brasileira De Normas Técnicas - ABNT. NBR 7190. Projeto de estruturas de madeira. Rio de Janeiro, 107 p., 1997.

[9] Lobão, M. S.; Lúcia, R. M. D.; Moreira, M. S. S.; Gomes, A. Caracterização das propriedades físico-mecânicas da madeira de Eucalipto com diferentes densidades. Revista Árvore, Viçosa-MG, v.28, n.6, p. 889-894, 2004.

[10] Almeida, D. H.; Scaliante, R. M.; Christoforo, A. L.; Varanda, L. D.; Lahr, F. A. R.; Dias, A. A.; Junior, C. C. Tenacidade da madeira como função da densidade aparente, Revista Árvore, Viçosa-MG, v.38, n.1, p.203-207, 2014.

[11] Mesquita, M. R.; Ferraz, I. D. K.; Camargo, J. L. C. Angelim vermelho, Dinizia excelsa Ducke. In: Manual de Sementes da Amazônia. Fascículo, v. 8, 12p. INPA, Manaus-AM, Brasil, 2009.

[12] Grobério, M. P.; Lahr, F. A. R. Indicações para o emprego da madeira de espécies tropicais do Brasil, Madeira: arquitetura e engenharia, n. 8, 2002.

[13] Rocha, H. L. S.; Paes, J. B.; Miná, A. J. S.; Oliveira, E. Caracterização físico mecânica da madeira de jurema - preta (Mimosa tenuiflora) visando seu emprego na indústria moveleira. Agrária, Recife - PE, v.10, n. 2, p. 262-267, 2015.

[14] Braz, R. L.; Oliveira, J. T. S.; Rodrigues, B. P.; Arantes, M. D. C. Propriedades físicas e mecânicas da madeira de Tppnia ciliata em diferentes idades. Floresta, Curitiba - PR, v. 43, n. 4, p. 663-670, out./dez. 2013.

[15] Torres, P. M. A.; Paes, J. B.; Nascimento, J. W. B.; Brito, F. M. S. Caracterização físico-mecânica da madeira jovem de Eucalyptus camaldulensis para aplicação na arquitetura rural. Floresta e Ambiente, Seropédica - RJ, v. 23, n.1, p. 109-117, 2016.

[16] Muller, B. V.; Rocha, M. P.; Cunha, A. B.; Klitzke, R. J.; Nicoletti, M. F. Avaliação das Principais Propriedades Físicas e Mecânicas da Madeira de Eucalyptus benthamii Maiden et Cambage, Floresta e Ambiente, v. 21, ed. 4, p. 535-542, 2014.

[17] Silveira, L. H. C.; Rezende, A. V.; Vale, A. T. Teor de umidade e densidade básica da madeira de nove espécies comerciais amazônicas, Acta Amazônica, v. 43, ed. 2, p. 179-184, 2013.

[18] Gonçalez, J. C.; Breda, L. C.; Barros, J. F. M.; Macedo, D. G.; Janin, G.; Costa, A. F.; Vale, A. T. Características tecnológicas das madeiras de Eucalyptus grandis W. Hill ex Maiden e Eucalyptus cloeziana F. Muell visando ao seu aproveitamento na indústria moveleira. Ciência Florestal, Santa Maria - RS, v. 16, n. 3, p. 329-341, 2006.

[19] MONTGOMERY, D. C. Design and analysis in experiments. Arizona: John Wiley \& Sons, 730p, 2012. 